\title{
Menarche, pregnancies, and breastfeeding do not modify long-term prognosis in multiple sclerosis
}

María I. Zuluaga, MD, Susana Otero-Romero, MD, PhD, Alex Rovira, MD, Santiago Perez-Hoyos, BSc, PhD, Georgina Arrambide, MD, PhD, Laura Negrotto, MD, Ingrid Galán, MD, Jordi Río, MD, PhD,

Manuel Comabella, MD, PhD, Carlos Nos, MD, María Jesús Arévalo, PhD, Angela Vidal-jordana, MD, PhD, Joaquin Castilló, MD, PhD, Breogán Rodríguez, MD, Luciana Midaglia, MD, Patricia Mulero, MD,

Raquel Mitjana, MD, Cristina Auger, MD, Jaume Sastre-Garriga, MD, PhD, Xavier Montalban, MD, PhD, * and Mar Tintoré, MD, PhD*

Neurology ${ }^{\circledR}$ 2019;92:e1507-e1516. doi:10.1212/WNL.0000000000007178

\section{Abstract}

\section{Objective}

To investigate the effect of menarche, pregnancies, and breastfeeding on the risk of developing multiple sclerosis (MS) and disability accrual using a multivariate approach based on a large prospective cohort of patients with clinically isolated syndrome (CIS).

\section{Methods}

A cross-sectional survey of the reproductive information of female participants in a CIS cohort was performed. We examined the relationship of age at menarche with the risk of clinically definite MS (CDMS), McDonald 2010 MS, and Expanded Disability Status Scale (EDSS) 3.0 and 6.0. The effect of pregnancy (before and after CIS) and breastfeeding in the risk of CDMS, McDonald 2010 MS, and EDSS 3.0 was also examined. Univariate and multivariate analyses were performed and findings were confirmed using sensitivity analyses and a propensity score model.

\section{Results}

The data of 501 female participants were collected. Age at menarche did not correlate with age at CIS and was not associated with the risk of CDMS or EDSS 3.0 or 6.0. Pregnancy before CIS was protective for CDMS in the univariate analysis, but the effect was lost in the multivariate model and did not modify the risk of EDSS 3.0. Pregnancy after CIS was protective for both outcomes in univariate and multivariate analyses when pregnancy was considered a baseline variable, but the protective effect disappeared when analyzed as a time-dependent event. Breastfeeding did not modify the risk for the 3 outcomes.

\section{Conclusions}

These results demonstrate that menarche, pregnancies, and breastfeeding did not substantially modify the risk of CDMS or disability accrual using a multivariable and time-dependent approach.

\author{
Correspondence \\ Dr. Tintoré \\ mtintore@cem-cat.org
}




\section{Glossary}

aHR = adjusted hazard ratio; $\mathbf{B M I}=$ body mass index; $\mathbf{C D M S}=$ clinically definite multiple sclerosis; $\mathbf{C I}=$ confidence interval; CIS = clinically isolated syndrome; DMT = disease-modifying treatment; EDSS = Expanded Disability Status Scale; HR = hazard ratio; $\mathbf{M S}=$ multiple sclerosis; $\mathbf{O B}=$ oligoclonal bands.

Consistent data show that women worldwide are at higher risk for multiple sclerosis (MS), with an incidence sex ratio of 2:1, which increased over the last 2 decades. ${ }^{1}$ However, there is conflicting evidence on the role of sex in MS prognosis. Large natural history studies reported a longer time from clinically isolated syndrome (CIS) to second attack and secondary progressive MS in women compared to men. ${ }^{2,3}$ However, other studies did not observe a protective role of female sex for the risk of second attack and only a mild effect in MS prognosis using a multivariate analysis. ${ }^{4}$

The increased MS risk in women suggests differences in the immune system or CNS between women and men, which may be caused by genetic dissimilarities, sex hormones, and environmental exposures. Nonhormonal factors may include smoking, history of Epstein-Barr virus infection, vitamin D deficiency, high body mass index (BMI), and high sodium intake. ${ }^{5-8}$ Regarding hormonal factors, previous studies demonstrated that women with MS exhibited younger age at menarche compared to healthy controls, ${ }^{9}$ and an earlier menarche was associated with a younger age at CIS. ${ }^{10}$

The short-term effect of pregnancy has been studied previously; results demonstrate that relapse risk decreases during pregnancy, but increases during the postpartum period due to hormonal changes occurring during these periods. ${ }^{11,12}$ However, the role of pregnancy and breastfeeding in the longterm prognosis of MS remains controversial.

We initiated the BARCELONA MS\&GENDER project to elucidate the role of hormonal factors in the modulation of MS prognosis. The present substudy investigated the role of menarche, pregnancies, and breastfeeding in MS prognosis.

\section{Methods}

\section{Study design}

This study was an observational study based on an ongoing prospective CIS cohort. This cohort began in 1995 and includes patients aged $<50$ years who exhibited a CIS suggestive of CNS demyelination not attributable to other diseases with symptom onset within 3 months of the first clinical evaluation. Clinical, demographic, CSF, and MRI information were prospectively collected using a prespecified protocol. Brain MRIs were performed at baseline and were repeated after 12 months and every 5 years thereafter. A baseline spinal cord MRI was only performed when patients presented with spinal cord syndrome from 1995 to 2006, but these data were collected for all patients with CIS beginning in
2007. The patients were seen on a regular basis for clinical evaluation, which included Expanded Disability Status Scale (EDSS) evaluation and relapses. The patients who did not attend 2 consecutive follow-up visits were defined as lost to follow-up. ${ }^{4}$

Female patients from the previously described cohort were invited to participate in the MS Gender Project. Their clinical, demographic, CSF, and MRI data were obtained from the prospectively collected data within the cohort. These patients also completed a self-administered survey that retrospectively collected reproductive information, external hormonal exposures, and other environmental risk factors (variables described in table 1). Participants were also asked to report their body size self-perception by selecting 1 of 9 body silhouettes on the Stunkard figure rating scale ${ }^{13}$ at the age of menarche and CIS, ranging from very thin to extremely obese, which is a accepted as a proxy of measure for BMI.

The survey was completed from February 2015 until November 2015 during the participants' regular clinical assessments using a tablet device or a printed version or via email with the patient's consent. An invitation to participate with the link to access the survey online was sent. A reminder email was sent up to 3 times if the patient did not fill out the survey after the first email invitation. Any missing or ambiguous data were confirmed during clinical visits or telephone. This survey was validated in nonmedical field women and required 5-10 minutes to complete.

Descriptive statistics were obtained for the demographic, clinical, CSF, and MRI variables and specific reproductive information (i.e., age at menarche, pregnancies, and breastfeeding). Spearman correlation examined the relationships of age at menarche with age at CIS and age at menarche with age at MS. Given that a different disease onset (multifocal or with encephalopathy) and evolution with high frequency of relapses in the first few years was described for pediatriconset MS, ${ }^{14}$ a separate analysis of age at menarche was performed in the group of female participants who experienced their CIS before age 18 .

The effect of menarche on the time to CIS for the studied outcomes CDMS, McDonald 2010, EDSS 3.0 and 6.0) was evaluated using a Cox regression analysis adjusted by age at CIS, topography, oligoclonal bands (OB), MRI, treatment, and body size at age at menarche. Confounders were selected based on the results of the studies previously performed in the same 
Table 1 Variables included in the survey

\begin{tabular}{l}
\hline Reproductive background \\
\hline Menarche \\
\hline Pregnancy outcomes \\
\hline Breastfeeding \\
\hline Menopause \\
\hline Honphysiologic hormonal exposure \\
\hline Fertility treatment \\
\hline Hormone replacement therapy \\
\hline Environmental risk factors \\
\hline Smoking
\end{tabular}

Abbreviations: CDMS = clinically definite multiple sclerosis; CIS = clinically isolated syndrome.

cohort. ${ }^{4}$ A subgroup analysis compared the age at menarche between 2 different prognostic profile groups (high-risk and low-risk female participants). The high-risk group (CISCDMS) included female participants who had an abnormal baseline MRI and positive $\mathrm{OB}$ and presented with a second attack during the follow-up. The low-risk group (CIS-CIS) included female participants who had a normal baseline MRI, negative $\mathrm{OB}$, and no second attack during the follow-up.

The effect of pregnancy (before and after CIS) on the time to CDMS, McDonald 2010 MS, and EDSS 3.0 and 6.0 was evaluated using a Cox regression analysis. Pregnancy after CIS was analyzed using 2 methods. First, we used a dichotomic variable that classified female participants who experienced pregnancy or not at any time during follow-up, and exposure to pregnancy was considered present from baseline. Univariate and multivariate Cox models adjusted by age at CIS, topography, OB, MRI, and disease-modifying treatment (DMT) prior to a second attack (as a time-dependent variable) were obtained. Second, we introduced pregnancy and breastfeeding into the model as time-dependent covariates. A woman was considered nonexposed to pregnancy until the moment of delivery and exposed after pregnancy (until outcome fulfilment or censored). Hazard ratio (HR) was interpreted as the excess or shortage of risk of the studied outcomes (CDMS, McDonald 2010 MS, EDSS 3.0 and 6.0) for 2 female participants with the same follow-up time from CIS in this second analysis. Finally, we confirmed our findings by fitting a propensity score model for pregnancy at any time using inverse probability weighting. These models controlled for selection bias because participants who became pregnant could exhibit different prognoses. Weights calculated after fitting a logistic model to estimate the probability of becoming pregnant over follow-up included age, previous pregnancy, topography, OB, MRI lesions, DMT, and CDMS before pregnancy.

The effect of breastfeeding on the time to CDMS, McDonald 2010 MS, and EDSS 3.0 was evaluated using Cox regression analysis with a 3-categorical variable: nonpregnancy (reference category), pregnancy without breastfeeding, and pregnancy with breastfeeding. First, we used a variable that classified participants who were breastfeeding or not at any time during follow-up, and exposure to breastfeeding was considered present from baseline. Univariate and multivariate Cox models adjusted by age at CIS, topography, OB, MRI, and DMT prior to a second attack (as a time-dependent variable) were obtained. Second, we introduced breastfeeding into the model as a time-dependent covariate. A woman was considered nonexposed to breastfeeding until the moment of breastfeeding and exposed thereafter (until outcome fulfilment or censored). HR was interpreted as the excess or shortage of risk of the studied outcomes for 2 women with the same follow-up time from CIS in this second analysis.

Sensitivity analyses were performed using the calculated conception date (delivery date minus 9 months), and pregnancy and abortion after CIS were considered.

\section{Standard protocol approvals, registrations, and patient consents}

This study was performed with the approval of the Ethics Committee of Hospital Universitari Vall d' Hebron. All patients signed a written informed consent form from the inclusion in the ongoing CIS cohort.

\section{Data availability}

Anonymized data will be shared by request from any qualified investigator.

\section{Results}

A total of 1,196 patients were enrolled in the prospective CIS cohort study from January 1995 to November 2015. Sixty-nine (6.1\%) patients did not meet the general inclusion criteria of the cohort and were excluded (exceeded entry window, previous attack, age over 50 years, and alternative diagnosis).

The female/male ratio of the remaining 1,127 patients was 2:1, of which 771 (68.4\%) were female. A total of 501 female participants completed the survey (65\% return rate). Patients who filled out the survey had a similar age at CIS (31.1 vs 31 years, $p=0.84$ ) but were more prone to exhibit an abnormal baseline MRI ( $82 \%$ vs $59 \%, p<0.005$ ), were more frequently 
on DMT ( $53 \%$ vs $16 \%, p<0.005$ ), and had a longer follow-up (9.5 vs 5.3 years, $p<0.005$ ). During follow-up, a total of $53 \%$ of patients had a second attack; $61 \%$ met the McDonald 2010 MRI MS criteria, $13.4 \%$ reached confirmed EDSS 3.0, and $2.6 \%$ EDSS 6.0 (table 2).

Table 2 Patient characteristics

\begin{tabular}{|c|c|}
\hline Baseline characteristics & Values \\
\hline Age at CIS, y, mean (SD) $(n=492)$ & $31.1(7.8)$ \\
\hline Age at menarche, $y$, mean (SD) $(n=501)$ & $12.5(1.6)$ \\
\hline Time from menarche to CIS, y, mean (SD) $(n=492)$ & $18.5(8)$ \\
\hline \multicolumn{2}{|l|}{ Initial symptom, n (\%) } \\
\hline Optic neuritis & $160(32)$ \\
\hline Myelitis & $147(30)$ \\
\hline Brainstem syndrome & $135(26)$ \\
\hline Other & $59(12)$ \\
\hline Oligoclonal bands, $\mathbf{n}(\%)$ & $n=428$ \\
\hline Positive & $273(64)$ \\
\hline Negative & $155(36)$ \\
\hline Basal MRI: T2 lesions, n(\%) & 481 \\
\hline None & $106(22)$ \\
\hline $1-3$ & $70(14.5)$ \\
\hline 4-9 & $68(14)$ \\
\hline$\geq 10$ & $237(49)$ \\
\hline Gadolinium enhancement, median (P25-P75) & $0(0-1)$ \\
\hline Barkhof criteria, n (\%) & $n=489$ \\
\hline 0 Barkhof criteria & $158(32)$ \\
\hline 1-2 Barkhof criteria & $108(22)$ \\
\hline 3-4 Barkhof criteria & $223(46)$ \\
\hline On DMT, n (\%) & $265(23)$ \\
\hline Weight, n (\%) & $n=501$ \\
\hline Underweight & $280(56)$ \\
\hline Normal & $192(38)$ \\
\hline Overweight & $29(6)$ \\
\hline \multicolumn{2}{|l|}{ Study outcomes } \\
\hline CDMS during follow-up, $n$ (\%) & $267(53)$ \\
\hline McDonald MS during follow-up, $n$ (\%) & $306(61)$ \\
\hline EDSS 3.0 during follow-up, $n$ (\%) & $67(13)$ \\
\hline EDSS 6.0 during follow-up, $n$ (\%) & $13(2.5)$ \\
\hline
\end{tabular}

Abbreviations: CDMS = clinically definitive multiple sclerosis; CIS = clinically isolated syndrome; DMT = disease-modifying treatment; EDSS = Expanded Disability Status Scale; MS = multiple sclerosis.

\section{Menarche}

The mean age at menarche was 12.5 years (SD 1.62), and the time from menarche to CIS was 18.5 (SD 8.0) years. Comparisons of demographic, clinical, and MRI data between patients with age at menarche before or after age 12.5 years revealed that the only significant difference was the time from menarche to CIS (18.5 vs 19.7 years, $p=0.001$ ). This difference was explained by the difference in age at menarche but not by the difference in age at CIS ( 30.9 vs 31.9 years, $p=$ 0.62). We performed correlation tests between the age at menarche and age at CIS to further confirm this observation and found no significant correlations $(p=0.94)$ between age at menarche and age at CDMS $(p=0.6)$ or EDSS $3.0(p=0.2)$.

Age at menarche was also not related to the risk of second attack (HR 1.03, 95\% confidence interval [CI] [0.81-1.31], $p=0.828$ ), McDonald 2010 MS (HR 0.93, 95\% CI [0.74-1.16], $p=0.513$ ), or disability accrual (EDSS $3.0 \mathrm{HR}$ $1.09,95 \%$ CI [0.67-1.77], $p=0.728$; EDSS 6.0 HR 0.60, 95\% CI $[0.20-1.85], p=0.377)$, even after adjusting for age at CIS, topography, OB, MRI, treatment, and body size at menarche (table 3). Subgroup analysis comparing the age at menarche between the high-risk (CIS-CDMS $n=181$ ) and low-risk (CIS-CIS $\mathrm{n}=68$ ) group revealed no significant differences $(p=0.281)$.

A separate analysis of female participants with CIS under the age of 18 years $(n=16)$ demonstrated that the mean age at CIS was 15.8 (SD 1.3) years. The age at menarche in this subgroup was 12.3 (SD 1.2) years, which was not different from female participants with CIS after 18 years of age ( 12.3 vs $12.5, p=0.55$ ). None of these patients had CIS before menarche, including the youngest patient at CIS, who was 12 years old. She experienced her menarche at 11 years of age. Eleven $(68.8 \%)$ patients had a second attack after a median of 12.2 (1.54-122) months. Thirteen (81\%) girls met McDonald 2010 MS after a median of 12.1 (1.54-179) months. One patient reached EDSS 3.036 months after the CIS.

\section{Pregnancy}

A total of 302 (60\%) of the 501 female participants who filled out the survey had at least one pregnancy prior to a CIS or during follow-up. Comparison of nulliparous female participants vs female participants with at least one pregnancy demonstrated that nulliparous women exhibited CIS at a younger age ( 28 vs 33 years, $p<0.005$ ), had higher lesion T2 load in the basal MRI ( 10 vs $7, p=0.02$ ), and were more frequently on DMT $(62.1 \%$ vs $49.3 \%, p<0.005)$.

\section{Pregnancy prior to CIS}

A total of 191 (38\%) female participants had at least one pregnancy prior to their CIS, and the mean age at CIS in this group was 37 years. Univariate analysis revealed that pregnancy prior to CIS was highly protective for CDMS (HR 0.62, 95\% CI $0.47-0.80, p<0.001$ ) and McDonald 2010 MS (HR 0.68, $95 \%$ CI $0.53-0.86, p=0.001)$. This effect was lost in the multivariate analysis when adjusting for age at CIS, topography, 
Table 3 Cox regression analysis for age at menarche and clinically definitive multiple sclerosis (CDMS), McDonald 2010 MS, and Expanded Disability Status Scale (EDSS) 3.0 and 6.0

\begin{tabular}{|c|c|c|c|c|c|c|}
\hline & HR & $95 \% \mathrm{Cl}$ & $p$ Value & $\mathrm{aHR}^{\mathrm{a}}$ & $95 \% \mathrm{Cl}$ & $p$ Value \\
\hline \multicolumn{7}{|c|}{ Time to CDMS } \\
\hline \multicolumn{7}{|c|}{ Age at menarche, $y$} \\
\hline$<12.5$ & 1.0 (Ref) & & & 1.0 (Ref) & & \\
\hline$\geq 12.5$ & 1.03 & $0.81-1.31$ & 0.828 & 0.94 & $0.74-1.21$ & 0.651 \\
\hline \multicolumn{7}{|c|}{ Time to McDonald 2010} \\
\hline \multicolumn{7}{|c|}{ Age at menarche, $y$} \\
\hline$<12.5$ & 1.0 (Ref) & & & 1.0 (Ref) & & \\
\hline$\geq 12.5$ & 0.93 & $0.74-1.16$ & 0.513 & 0.89 & $0.70-1.12$ & 0.327 \\
\hline \multicolumn{7}{|c|}{ Time to EDSS 3.0} \\
\hline \multicolumn{7}{|c|}{ Age at menarche, $y$} \\
\hline$<12.5$ & 1.0 (Ref) & & & 1.0 (Ref) & & \\
\hline$\geq 12.5$ & 1.09 & $0.67-1.77$ & 0.728 & 1.15 & $0.70-1.92$ & 0.579 \\
\hline \multicolumn{7}{|c|}{ Time to EDSS 6.0} \\
\hline \multicolumn{7}{|c|}{ Age at menarche, $y$} \\
\hline$<12.5$ & 1.0 (Ref) & & & 1.0 (Ref) & & \\
\hline$\geq 12.5$ & 0.60 & $0.20-1.85$ & 0.377 & 0.60 & $0.19-1.90$ & 0.383 \\
\hline
\end{tabular}

Abbreviations: aHR = adjusted hazard ratio for the multivariate model; $\mathrm{Cl}=$ confidence interval; $\mathrm{HR}=\mathrm{hazard}$ ratio; $\mathrm{OB}=\mathrm{oligoclonal}$ bands. adjusted by age at clinically isolated syndrome, topography, OB, MRI, disease-modifying treatment, and body size at menarche.

OB, MRI, and DMT for CDMS (adjusted HR [aHR] 1.09, 95\% CI 0.79-1.51, $p=0.589$ ) and McDonald $2010 \mathrm{MS}$ (aHR $1.24,95 \%$ CI $0.91-1.69, p=0.17)$. Pregnancy prior to CIS did not modify the risk of attaining confirmed EDSS 3.0 in the univariate (HR $1.05,95 \% \mathrm{CI} 0.6-1.7, p=0.837$ ) or multivariate (aHR 1.3, 95\% CI 0.7-2.7, $p=0.392$ ) analyses.

\section{Pregnancy after CIS}

A total of 142 (28\%) women had at least one pregnancy after the CIS, and the mean age at CIS in this group was 27 years.

Univariate analysis revealed a protective effect of pregnancy for CDMS (HR 0.30, 95\% CI 0.20-0.46, $p<0.001$ ), McDonald 2010 MS (HR 0.22, 95\% CI 0.14-0.35, $p<0.001$ ), and confirmed EDSS 3.0 (HR 0.43, 95\% CI 0.24-0.80, $p=0.0073$ ).

Multivariate analyses using pregnancy as a baseline variable revealed that the protective effect persisted for CDMS (aHR $0.25,95 \%$ CI $0.16-0.38, p<0.001$ ), McDonald 2010 MS (aHR 0.23, 95\% CI 0.14-0.37, $p<0.001$ ), and disability accrual (aHR 0.45, 95\% CI 0.23-0.89, $p=0.008$ ). However, the protective effect disappeared for CDMS (aHR 1.13, 95\% CI $0.70-1.82, p=0.6$ ), McDonald 2010 MS (HR 1.01, 95\% CI $0.60-1.73, p=0.90$ ), and confirmed EDSS 3.0 (HR 0.89, $95 \%$ CI $0.44-1.80, p=0.97$ ) when pregnancy was analyzed as a time-dependent event. We could not conduct the survival analysis for EDSS 6 given that none of the pregnant women after CIS reached EDSS 6 over follow-up. These results indicate that the moment at which a woman becomes pregnant did not affect the development of the 3 outcomes.

Propensity score analysis confirmed these results for CDMS (aHR 1.14, 95\% CI 0.63-2.06, $p=0.66$ ), McDonald 2010 MS (HR 1.71, 95\% CI 0.88-3.33, $p=0.24$ ), and EDSS 3.0 (aHR 1.03 , 95\% CI 0.43-2.50, $p=0.94$ ) (figure 1 ).

\section{Breastfeeding}

For the 133 pregnancies that occurred after the CIS but before EDSS 3.0, 87 female participants breastfed. Differences in the risk of CDMS, McDonald 2010 MS, and EDSS 3.0 were compared to patients who became pregnant and did not breastfeed as a reference. No differences were observed between breastfeeding and nonbreastfeeding groups for all 3 outcomes. The observed HRs were 1.41 (95\% CI 0.61-3.23, $p=0.42)$ for CDMS, 1.42 (95\% CI 0.5-3.67, $p=0.46)$ for McDonald 2010 MS, and 1.21 (95\% CI 0.37-3.93, $p=0.75$ ) for EDSS 3.0.

Multivariate analyses of breastfeeding vs nonbreastfeeding groups revealed that no significant differences remained, but the direction of a marginal effect of breastfeeding appeared (CDMS: aHR 0.92, 95\% CI 0.39-2.14, $p=0.84$; McDonald 2010: aHR 0.73, 95\% CI 0.27-1.96, $p=0.53$; and EDSS 3.0: aHR $0.85,95 \%$ CI $0.25-2.84, p=0.79)$. 
Figure 1 Effect of pregnancy after clinically isolated syndrome (CIS) on the time to clinically definite multiple sclerosis (CDMS), McDonald 2010 MS, and Expanded Disability Status Scale (EDSS) 3.0

\section{A. CDMS}

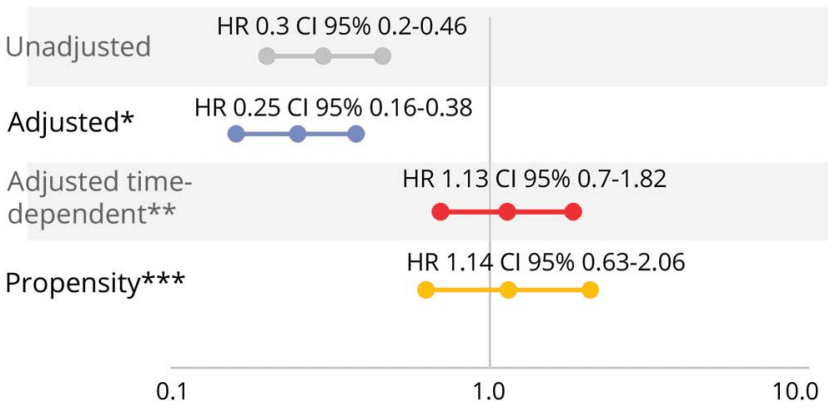

\section{B. McDonald 2010}

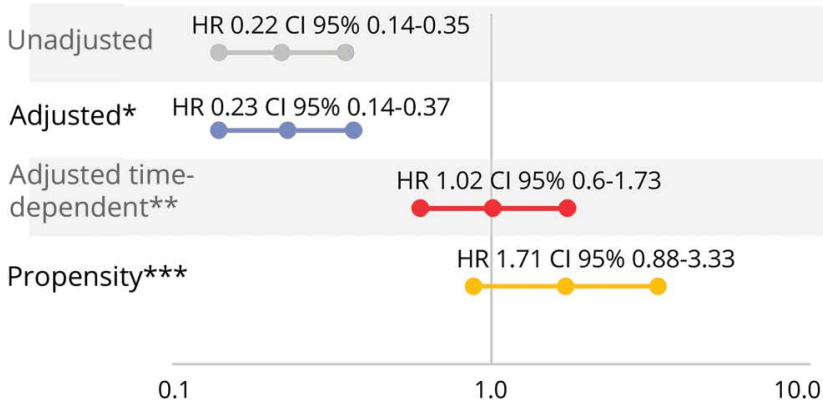

\section{EDSS 3.0}

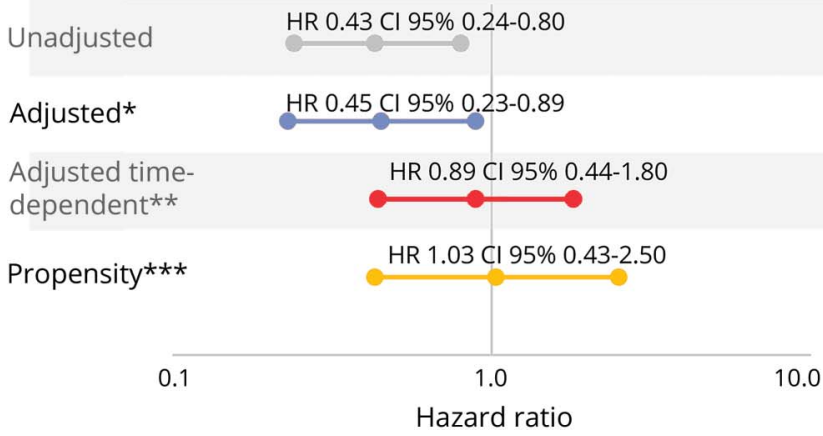

$\mathrm{Cl}=$ confidence interval; $\mathrm{HR}$ = hazard ratio; $\mathrm{OB}$ = oligoclonal bands. *Adjusted by age at CIS, topography, OB, MRI, and disease-modifying treatment prior to a second attack (as a time-dependent variable). **Adjusted by age at CIS, topography, $\mathrm{OB}, \mathrm{MRI}$, and disease-modifying treatment prior to a second attack (as a timedependent variable) and pregnancy as a time-dependent covariate. ***Propensity score model for pregnancy at any time using inverse probability weighting.

Analysis of breastfeeding as a time-dependent event revealed that no significant differences remained for CDMS (aHR 1.09 , 95\% CI $0.47-2.54, p=0.84$ ) or McDonald $2010 \mathrm{MS}$ (HR 0.86, 95\% CI 0.32-2.29, $p=0.77$ ) and confirmed the EDSS 3.0 result (HR 0.97, 95\% CI 0.29-3.26, $p=0.97$ ) (figure 2). These results were confirmed in the sensitivity analyses, which considered new T2 lesions during follow-up and time to CDMS (CDMS: HR 1.10, 95\% CI 0.47-2.59, $p=$ 0.83; McDonald 2010: aHR 0.54, 95\% CI 0.20-1.45, $p=0.22$; EDSS: HR 0.74, 95\% CI 0.21-2.59, $p=0.64)$.
Figure 2 Effect of breastfeeding on the time to clinically definite multiple sclerosis (CDMS), McDonald 2010 MS, and Expanded Disability Status Scale (EDSS) 3.0

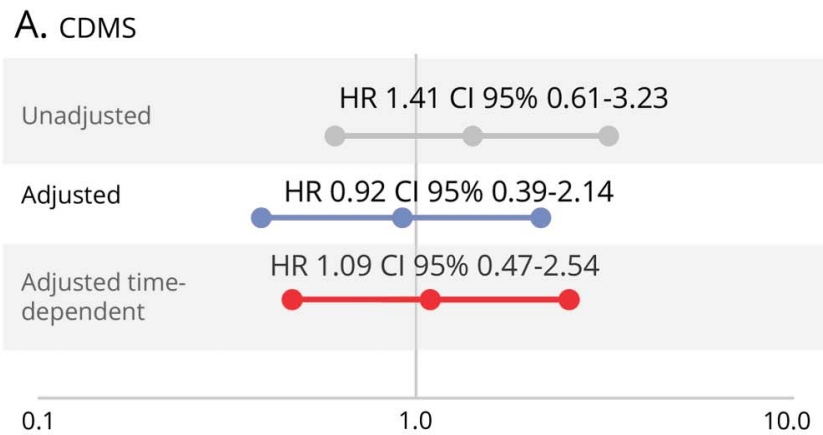

B. McDonald 2010

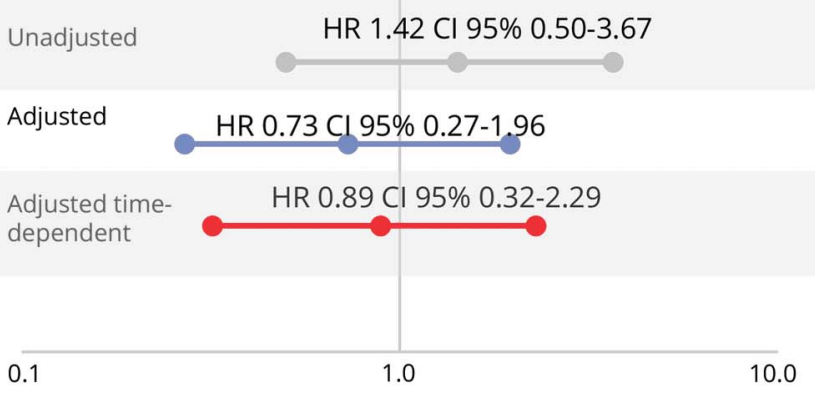

C. EDSS 3.0

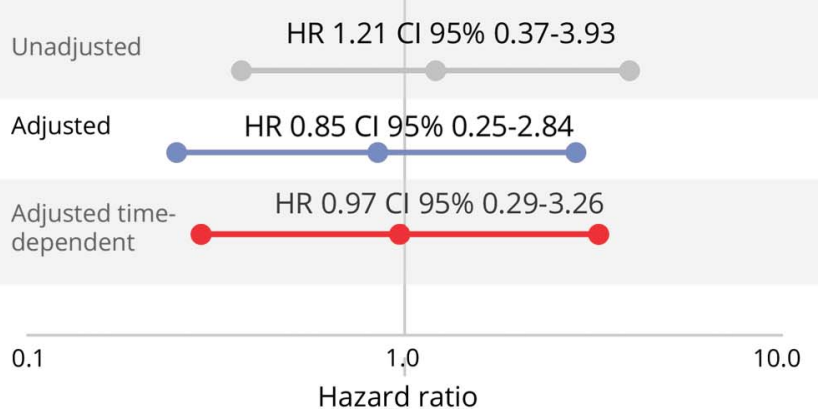

$\mathrm{Cl}=$ confidence interval; $\mathrm{HR}=$ hazard ratio; $\mathrm{OB}=$ oligoclonal bands. *Adjusted by age at clinically isolated syndrome (CIS), topography, OB, MRI, and diseasemodifying treatment prior to a second attack (as a time-dependent variable). ${ }^{\star \star}$ Adjusted by age at CIS, topography, OB, MRI, and disease-modifying treatment prior to a second attack (as a time-dependent variable) and breastfeeding as a time-dependent covariate.

\section{Discussion}

The effect of hormonal changes during the female reproductive life in the short and long term prognosis of MS have been previously addressed.

Regarding menarche, the evidence of the effect of age at menarche on age at MS onset and the risk and prognosis of MS is inconclusive. It is known that puberty encompasses several years and begins in girls between 8 and 12 years. Menarche represents the end of puberty and is regulated by genetic and 
several environmental factors (BMI, diet, and exercise). ${ }^{15,16}$ It has been hypothesized that early menarche or earlier sexual maturation will involve more prolonged exposure to sexual hormones, which might be related to an increased risk of MS. A Canadian study reported an increased risk of MS in women with a younger age at menarche-menarche in controls occurred at 12.6 years compared to 12.4 years in patients with MS $(p=0.00017)$ - but did not find any association between age at menarche and age at MS onset. ${ }^{9}$ Our study did not include controls and cannot address this specific question; however, we did not find a relationship between age at puberty and age at MS onset or long-term clinical course of the disease (risk of second attack, McDonald MS, risk of disability) even after controlling for age at CIS, topography, OB, MRI, treatment, and body size self-perception at menarche. A complementary subgroup analysis comparing the high-risk group (CIS-CDMS) and the low-risk group (CIS-CIS) did not observe differences in the age at menarche and age at CIS. ${ }^{10}$

A separate analysis of the female participants in our cohort with a CIS before the age of 18 years was performed. None of these patients with pediatric onset had their CIS before menarche, and the age at menarche was not different from the rest of the group. However, a selection bias cannot be excluded because patients under the age of 12 years were likely underrepresented in our cohort. Another potential limitation of our study is recall bias because the age of menarche was collected retrospectively. Women may remember the year but not the exact date of the menarche; however, previous studies demonstrated good reliability of the approximated age at menarche. ${ }^{17}$ This should be taken into account since the previous studies reported significant differences based on a very small difference (months) of onset of menarche between the groups. ${ }^{9}$ It is therefore difficult to establish a causal relationship between that small difference in age at menarche reported in previous studies and the risk of such a complex disease as MS. To overcome this limitation in the future, we have started to collect this information prospectively.

The effect of pregnancy on the risk and evolution of MS has been widely studied. Previous evidence supports a protective effect of pregnancies on risk and short-term prognosis, decreasing clinical inflammatory activity, especially during the last trimester. ${ }^{20,21}$

Higher parity has been associated with a decreased risk of having a first clinical demyelinating event ${ }^{18,19}$ and pregnancy was associated with a decreased risk of disability progression (EDSS 6.0) compared to a nulliparous status. ${ }^{20-24}$ The protective effect of pregnancy after CIS on long-term outcomes was recently addressed in a very large real-life cohort (MSBase). This study considered pregnancy as a baseline and not a time-dependent variable and found that female participants with at least one pregnancy exhibited a lower EDSS score over 10 years after a propensity score adjustment. ${ }^{25}$ In contrast, this protective long-term effect was not found in other studies that examined the possible association between parity and the risk of disability accrual or secondary progressive MS. ${ }^{26,27}$ However, none of these studies considered the interaction of other known confounding factors, such as age at CIS, CIS topography, OB, burden of T2 lesion, and the use of DMT.

Postpartum is a critical time for women with MS. The protective effect of pregnancy is lost, and mothers must decide whether to restart early treatment or breastfeed. ${ }^{28}$ Some studies suggested that breastfeeding modestly reduces the risk of postpartum relapses ${ }^{29-32}$; others have reported that breastfeeding was not related to postpartum relapses, and relapse rates before or during pregnancy were the main factors that determined the risk of relapse during the postpartum period. ${ }^{33}$ The potential protective effect of breastfeeding in MS prognosis may be at least partially explained by selection bias because women with milder disease activity and less disability would be more prone to breastfeed their children compared to patients with more active disease. ${ }^{28}$ Again, controlling for previously known prognostic factors and performing time-dependent analyses may help to avoid selection bias and weight accurately the real effect of breastfeeding.

Our study has 2 important strengths. The first strength is the characteristics and number of patients included in this report. These female participants are part of a prospective, open CIS cohort with a long follow-up, and they are evaluated on a regular basis. Demographic, clinical, MRI, and treatment information is recorded prospectively under a prespecified protocol. These high-quality data allow us to perform adjusted analyses for possible confounding factors.

The second strength lies in the statistical analyses used; with our time-dependent approach, the HR reflects the effect of pregnancy from the moment in which the patient becomes pregnant instead of treating it like a baseline covariate. In addition, breastfeeding was modeled analogously. In timefixed models one assumes that the exposure (in this case, pregnancy or breastfeeding) is present since the beginning of follow-up until the end of the course of the patient. Thus, ignoring the time-dependent nature of an exposure could lead to time-dependent bias. ${ }^{34}$ A propensity score over the pregnancy status was performed to avoid a probable selection bias. For instance, a woman with a mild progression of the disease could be more likely to be pregnant than a woman with a more aggressive course. This approach has been performed in other previous studies. ${ }^{35}$ However, in our study we have considered not only clinical variables for the multivariate analysis but biological (oligoclonal bands) and MRI data, and both factors are known to be important at the time to predict the course of MS. ${ }^{4}$

The results of this study provide us with useful information for women with MS regarding reproductive counseling. The main message is that the prognosis of MS will not be significantly affected by pregnancy once all other variables are considered. In this regard, the clinical activity, MRI findings, 
and early initiation of treatment are the most important prognostic factors that should be considered when addressing reproductive decisions.

It is known that the risk of MS is multifactorial, and hormones may play an important role in the risk of the disease, but this effect may be diminished once the disease is established. Future studies considering the exact time of menarche and the characteristics of breastfeeding in the overall disease course are required to further establish the association between reproductive background and MS prognosis.

\section{Study funding}

This project was supported by FIS PI15/0070 from Ministry of Economy and Competitiveness of Spain, Fundación Genzyme research grant, and ECTRIMS clinical fellowship awarded to María I. Zuluaga.

\section{Disclosure}

M. Zuluaga has received compensation for consulting services from Novartis, Stendhal, Genzyme, Merck-Serono, and Bayer. S. Otero-Romero reports no disclosures relevant to the manuscript. A. Rovira serves on scientific advisory boards for Biogen Idec, Novartis, Genzyme, and OLEA Medical, and on the editorial boards of the American Journal of Neuroradiology, Neuroradiology, and European Radiology; has received speaker honoraria from Bayer, Genzyme, Sanofi-Aventis, Bracco, Merck-Serono, Teva Pharmaceutical Industries Ltd., OLEA Medical, Stendhal, Novartis, and Biogen Idec; and has research agreements with Siemens AG. S. Perez-Hoyos reports no disclosures relevant to the manuscript. G. Arrambide has received compensation for consulting services from BiogenIdec, research support from Novartis, and speaking honoraria from Sanofi-Aventis. L. Negrotto and I. Galán report no disclosures relevant to the manuscript. J. Río has received speaking honoraria and personal compensation for participating on advisory boards from Almirall, Bayer-Schering Healthcare, Biogen-Idec, Genzyme, Merck-Serono, Novartis, Teva, and Sanofi-Aventis. M. Comabella has received compensation for consulting services and speaking honoraria from Bayer Schering Pharma, Merck Serono, Biogen-Idec, Teva Pharmaceuticals, Sanofi-Aventis, and Novartis. C. Nos has received funding for travel from Biogen Idec and F. Hoffmann-La Roche, Ltd., and speaker honoraria from Novartis. M. Arevalo reports no disclosures relevant to the manuscript. A. VidalJordana has received speaking honoraria and consulting fees from Novartis, Roche, and Sanofi-Aventis. J. Castilló, B. Rodríguez-Acevedo, L. Midaglia, P. Mulero, and R. Mitjana report no disclosures relevant to the manuscript. C. Auger has received speaking honoraria from Novartis, Biogen, and Stendhal. J. Sastre-Garriga has received compensation for participating on advisory boards, speaking honoraria, and travel expenses for scientific meetings, consulting services, or research support from Celgene, Novartis, Biogen, Teva, Merck, Almirall, and Genzyme. X. Montalban has received speaking honoraria and travel expenses for participation in scientific meetings and has been a steering committee member of clinical trials or participated in advisory boards of clinical trials in the past with Actelion, Amirall, Bayer, Biogen, Celgene, Genzyme, Hoffmann-La Roche, Novartis, Oryzon Genomics, Sanofi-Genzyme, and Teva Pharmaceutical. M. Tintoré has received compensation for consulting services and speaking honoraria from Bayer Schering Pharma, MerckSerono, Biogen-Idec, Teva Pharmaceuticals, Sanofi-Aventis, Novartis, Almirall, Genzyme, and Roche. Go to Neurology. org/ $\mathrm{N}$ for full disclosures.

\section{Publication history}

Received by Neurology June 3, 2018. Accepted in final form November 21, 2018.

\begin{tabular}{|c|c|c|c|}
\hline Name & Location & Role & Contribution \\
\hline $\begin{array}{l}\text { María I. } \\
\text { Zuluaga, } \\
\text { MD }\end{array}$ & $\begin{array}{l}\text { Centre d'Esclerosi } \\
\text { Múltiple de Catalunya } \\
\text { (Cemcat); Department } \\
\text { of Neurology/ } \\
\text { Neuroimmunology, } \\
\text { Hospital Universitari } \\
\text { Vall d'Hebron, } \\
\text { Barcelona, Spain }\end{array}$ & Author & $\begin{array}{l}\text { Designed and } \\
\text { conceptualized } \\
\text { the study, analyzed } \\
\text { the data, drafted the } \\
\text { manuscript for } \\
\text { intellectual content }\end{array}$ \\
\hline $\begin{array}{l}\text { Susana } \\
\text { Otero- } \\
\text { Romero, } \\
\text { PhD }\end{array}$ & $\begin{array}{l}\text { Centre d'Esclerosi } \\
\text { Múltiple de Catalunya } \\
\text { (Cemcat); Department } \\
\text { of Neurology/ } \\
\text { Neuroimmunology, } \\
\text { Hospital Universitari } \\
\text { Vall d'Hebron, } \\
\text { Barcelona, Spain }\end{array}$ & Author & $\begin{array}{l}\text { Designed and } \\
\text { conceptualized } \\
\text { the study, analyzed } \\
\text { the data, drafted the } \\
\text { manuscript for } \\
\text { intellectual content }\end{array}$ \\
\hline $\begin{array}{l}\text { Alex Rovira, } \\
\text { MD }\end{array}$ & $\begin{array}{l}\text { Unitat de RM, Servei } \\
\text { de Radiologia, } \\
\text { Hospital Universitari } \\
\text { Vall d'Hebron; } \\
\text { Universitat Autònoma } \\
\text { de Barcelona, Spain }\end{array}$ & Author & $\begin{array}{l}\text { Major role in the } \\
\text { acquisition of data }\end{array}$ \\
\hline $\begin{array}{l}\text { S. Perez- } \\
\text { Hoyos }\end{array}$ & $\begin{array}{l}\text { Unitat d'Estadística i } \\
\text { Bioinformàtica (UEB); } \\
\text { Vall d'Hebron Institut } \\
\text { de Recerca (VHIR), } \\
\text { Barcelona, Spain }\end{array}$ & Author & $\begin{array}{l}\text { Interpreted the data, } \\
\text { revised the } \\
\text { manuscript for } \\
\text { intellectual content }\end{array}$ \\
\hline $\begin{array}{l}\text { Georgina } \\
\text { Arrambide, } \\
\text { MD, PhD }\end{array}$ & $\begin{array}{l}\text { Centre d'Esclerosi } \\
\text { Múltiple de Catalunya } \\
\text { (Cemcat); Department } \\
\text { of Neurology/ } \\
\text { Neuroimmunology, } \\
\text { Hospital Universitari } \\
\text { Vall d'Hebron, } \\
\text { Barcelona, Spain }\end{array}$ & Author & $\begin{array}{l}\text { Major role in the } \\
\text { acquisition of data, } \\
\text { interpreted the data, } \\
\text { revised the } \\
\text { manuscript for } \\
\text { intellectual content }\end{array}$ \\
\hline $\begin{array}{l}\text { Laura } \\
\text { Negrotto, } \\
\text { MD }\end{array}$ & $\begin{array}{l}\text { Centre d'Esclerosi } \\
\text { Múltiple de Catalunya } \\
\text { (Cemcat); Department } \\
\text { of Neurology/ } \\
\text { Neuroimmunology, } \\
\text { Hospital Universitari } \\
\text { Vall d'Hebron, } \\
\text { Barcelona, Spain }\end{array}$ & Author & $\begin{array}{l}\text { Major role in the } \\
\text { acquisition of data }\end{array}$ \\
\hline $\begin{array}{l}\text { Ingrid } \\
\text { Galán, MD }\end{array}$ & $\begin{array}{l}\text { Centre d'Esclerosi } \\
\text { Múltiple de Catalunya } \\
\text { (Cemcat); Department } \\
\text { of Neurology/ } \\
\text { Neuroimmunology, } \\
\text { Hospital Universitari } \\
\text { Vall d'Hebron, } \\
\text { Barcelona, Spain }\end{array}$ & Author & $\begin{array}{l}\text { Major role in the } \\
\text { acquisition of data }\end{array}$ \\
\hline
\end{tabular}


Appendix (continued)

\begin{tabular}{|c|c|c|c|}
\hline Name & Location & Role & Contribution \\
\hline $\begin{array}{l}\text { Jordi Río, } \\
\text { MD, PhD }\end{array}$ & $\begin{array}{l}\text { Centre d'Esclerosi } \\
\text { Múltiple de Catalunya } \\
\text { (Cemcat); Department } \\
\text { of Neurology/ } \\
\text { Neuroimmunology, } \\
\text { Hospital Universitari } \\
\text { Vall d'Hebron, } \\
\text { Barcelona, Spain }\end{array}$ & Author & $\begin{array}{l}\text { Major role in the } \\
\text { acquisition of data }\end{array}$ \\
\hline $\begin{array}{l}\text { Manuel } \\
\text { Comabella, } \\
\text { MD, PhD }\end{array}$ & $\begin{array}{l}\text { Centre d'Esclerosi } \\
\text { Múltiple de Catalunya } \\
\text { (Cemcat); Department } \\
\text { of Neurology/ } \\
\text { Neuroimmunology, } \\
\text { Hospital Universitari } \\
\text { Vall d'Hebron, } \\
\text { Barcelona, Spain }\end{array}$ & Author & $\begin{array}{l}\text { Interpreted the data, } \\
\text { revised the } \\
\text { manuscript for } \\
\text { intellectual content }\end{array}$ \\
\hline $\begin{array}{l}\text { Carlos Nos, } \\
\text { MD }\end{array}$ & $\begin{array}{l}\text { Centre d'Esclerosi } \\
\text { Múltiple de Catalunya } \\
\text { (Cemcat); Department } \\
\text { of Neurology/ } \\
\text { Neuroimmunology, } \\
\text { Hospital Universitari } \\
\text { Vall d'Hebron, } \\
\text { Barcelona, Spain }\end{array}$ & Author & $\begin{array}{l}\text { Interpreted the data, } \\
\text { revised the } \\
\text { manuscript for } \\
\text { intellectual content }\end{array}$ \\
\hline $\begin{array}{l}\text { María Jesús } \\
\text { Arévalo, } \\
\text { PhD }\end{array}$ & $\begin{array}{l}\text { Centre d'Esclerosi } \\
\text { Múltiple de Catalunya } \\
\text { (Cemcat); Department } \\
\text { of Neurology/ } \\
\text { Neuroimmunology, } \\
\text { Hospital Universitari } \\
\text { Vall d'Hebron, } \\
\text { Barcelona, Spain }\end{array}$ & Author & $\begin{array}{l}\text { Interpreted the data, } \\
\text { revised the } \\
\text { manuscript for } \\
\text { intellectual content }\end{array}$ \\
\hline $\begin{array}{l}\text { Angela } \\
\text { Vidal- } \\
\text { Jordana, } \\
\text { MD, PhD }\end{array}$ & $\begin{array}{l}\text { Centre d'Esclerosi } \\
\text { Múltiple de Catalunya } \\
\text { (Cemcat); Department } \\
\text { of Neurology/ } \\
\text { Neuroimmunology, } \\
\text { Hospital Universitari } \\
\text { Vall d'Hebron, } \\
\text { Barcelona, Spain }\end{array}$ & Author & $\begin{array}{l}\text { Major role in the } \\
\text { acquisition of data }\end{array}$ \\
\hline $\begin{array}{l}\text { Joaquin } \\
\text { Castilló, } \\
\text { MD, PhD }\end{array}$ & $\begin{array}{l}\text { Centre d'Esclerosi } \\
\text { Múltiple de Catalunya } \\
\text { (Cemcat); Department } \\
\text { of Neurology/ } \\
\text { Neuroimmunology, } \\
\text { Hospital Universitari } \\
\text { Vall d'Hebron, } \\
\text { Barcelona, Spain }\end{array}$ & Author & $\begin{array}{l}\text { Major role in the } \\
\text { acquisition of data }\end{array}$ \\
\hline $\begin{array}{l}\text { Breogán } \\
\text { Rodríguez, } \\
\text { MD }\end{array}$ & $\begin{array}{l}\text { Centre d'Esclerosi } \\
\text { Múltiple de Catalunya } \\
\text { (Cemcat); Department } \\
\text { of Neurology/ } \\
\text { Neuroimmunology, } \\
\text { Hospital Universitari } \\
\text { Vall d'Hebron, } \\
\text { Barcelona, Spain }\end{array}$ & Author & $\begin{array}{l}\text { Major role in the } \\
\text { acquisition of data }\end{array}$ \\
\hline $\begin{array}{l}\text { Luciana } \\
\text { Midaglia, } \\
\text { MD }\end{array}$ & $\begin{array}{l}\text { Centre d'Esclerosi } \\
\text { Múltiple de Catalunya } \\
\text { (Cemcat); Department } \\
\text { of Neurology/ } \\
\text { Neuroimmunology, } \\
\text { Hospital Universitari } \\
\text { Vall d'Hebron, } \\
\text { Barcelona, Spain }\end{array}$ & Author & $\begin{array}{l}\text { Major role in the } \\
\text { acquisition of data }\end{array}$ \\
\hline
\end{tabular}

Appendix (continued)

\begin{tabular}{|c|c|c|c|}
\hline Name & Location & Role & Contribution \\
\hline $\begin{array}{l}\text { Patricia } \\
\text { Mulero, MD }\end{array}$ & $\begin{array}{l}\text { Centre d'Esclerosi } \\
\text { Múltiple de Catalunya } \\
\text { (Cemcat); Department } \\
\text { of Neurology/ } \\
\text { Neuroimmunology, } \\
\text { Hospital Universitari } \\
\text { Vall d'Hebron, } \\
\text { Barcelona, Spain }\end{array}$ & Author & $\begin{array}{l}\text { Major role in the } \\
\text { acquisition of data }\end{array}$ \\
\hline $\begin{array}{l}\text { Raquel } \\
\text { Mitjana, MD }\end{array}$ & $\begin{array}{l}\text { Unitat de RM, Servei } \\
\text { de Radiologia, } \\
\text { Hospital Universitari } \\
\text { Vall d'Hebron; } \\
\text { Universitat Autònoma } \\
\text { de Barcelona, Spain }\end{array}$ & Author & $\begin{array}{l}\text { Major role in the } \\
\text { acquisition of data }\end{array}$ \\
\hline $\begin{array}{l}\text { Cristina } \\
\text { Auger, MD }\end{array}$ & $\begin{array}{l}\text { Unitat de RM, Servei } \\
\text { de Radiologia, } \\
\text { Hospital Universitari } \\
\text { Vall d'Hebron; } \\
\text { Universitat Autònoma } \\
\text { de Barcelona, Spain }\end{array}$ & Author & $\begin{array}{l}\text { Major role in the } \\
\text { acquisition of data }\end{array}$ \\
\hline $\begin{array}{l}\text { Jaume } \\
\text { Sastre- } \\
\text { Garriga, } \\
\text { MD, PhD }\end{array}$ & $\begin{array}{l}\text { Centre d'Esclerosi } \\
\text { Múltiple de Catalunya } \\
\text { (Cemcat); Department } \\
\text { of Neurology/ } \\
\text { Neuroimmunology, } \\
\text { Hospital Universitari } \\
\text { Vall d'Hebron, } \\
\text { Barcelona, Spain }\end{array}$ & Author & $\begin{array}{l}\text { Interpreted the data, } \\
\text { revised the } \\
\text { manuscript for } \\
\text { intellectual content }\end{array}$ \\
\hline $\begin{array}{l}\text { Xavier } \\
\text { Montalban, } \\
\text { MD, PhD }\end{array}$ & $\begin{array}{l}\text { Centre d'Esclerosi } \\
\text { Múltiple de Catalunya } \\
\text { (Cemcat); Department } \\
\text { of Neurology/ } \\
\text { Neuroimmunology, } \\
\text { Hospital Universitari } \\
\text { Vall d'Hebron, } \\
\text { Barcelona, Spain }\end{array}$ & Author & $\begin{array}{l}\text { Interpreted the data, } \\
\text { revised the } \\
\text { manuscript for } \\
\text { intellectual content }\end{array}$ \\
\hline $\begin{array}{l}\text { Mar } \\
\text { Tintoré, } \\
\text { MD, PhD }\end{array}$ & $\begin{array}{l}\text { Centre d'Esclerosi } \\
\text { Múltiple de Catalunya } \\
\text { (Cemcat); Department } \\
\text { of Neurology/ } \\
\text { Neuroimmunology, } \\
\text { Hospital Universitari } \\
\text { Vall d'Hebron, } \\
\text { Barcelona, Spain }\end{array}$ & Author & $\begin{array}{l}\text { Designed and } \\
\text { conceptualized } \\
\text { study, analyzed the } \\
\text { data, drafted the } \\
\text { manuscript for } \\
\text { intellectual content }\end{array}$ \\
\hline
\end{tabular}

\section{References}

1. Trojano M, Lucchese G, Graziano G, et al. Geographical variations in sex ratio trends over time in multiple sclerosis. PLoS One 2012;7:e48078.

2. Koch M, Kingwell E, Rieckmann P, Tremlett H; UBC MS Clinic Neurologists. The natural history of secondary progressive multiple sclerosis. J Neurol Neurosurg Psychiatry 2010;81:1039-1043.

3. Debouverie M. Gender as a prognostic factor and its impact on the incidence of multiple sclerosis in Lorraine, France. J Neurol Sci 2009;286:14-17.

4. Tintore M, Rovira A, Río J, et al. Defining high, medium and low impact prognostic factors for developing multiple sclerosis. Brain J Neurol 2015;138:1863-1874.

5. Belbasis L, Bellou V, Evangelou E, Ioannidis JPA, Tzoulaki I. Environmental risk factors and multiple sclerosis: an umbrella review of systematic reviews and metaanalyses. Lancet Neurol 2015;14:263-273.

6. Kavak KS, Teter BE, Hagemeier J, Zakalik K, Weinstock-Guttman B; New York State Multiple Sclerosis Consortium. Higher weight in adolescence and young adulthood is associated with an earlier age at multiple sclerosis onset. Mult Scler 2015;21:858-865.

7. Farez MF, Fiol MP, Gaitán MI, Quintana FJ, Correale J. Sodium intake is associated with increased disease activity in multiple sclerosis. J Neurol Neurosurg Psychiatry 2015;86:26-31. 
8. Fitzgerald $\mathrm{KC}$, Munger KL, Hartung HP, et al. Sodium intake and multiple sclerosis activity and progression in BENEFIT. Ann Neurol 2017;82:20-29.

9. Ramagopalan SV, Valdar W, Criscuoli M, et al. Age of puberty and the risk of multiple sclerosis: a population based study. Eur J Neurol 2009;16:342-347.

10. Sloka JS, Pryse-Phillips WEM, Stefanelli M. The relation between menarche and the age of first symptoms in a multiple sclerosis cohort. Mult Scler 2006;12:333-339.

11. Confavreux C, Hutchinson M, Hours MM, Cortinovis-Tourniaire P, Moreau T. Rate of pregnancy-related relapse in multiple sclerosis: Pregnancy in Multiple Sclerosis Group. N Engl J Med 1998;339:285-291.

12. Vukusic S, Hutchinson M, Hours M, et al. Pregnancy and multiple sclerosis (the PRIMS study): clinical predictors of post-partum relapse. Brain J Neurol 2004;127: 1353-1360.

13. Stunkard AJ, Sørensen T, Schulsinger F. Use of the Danish Adoption Register for the study of obesity and thinness. Res Publ Assoc Res Nerv Ment Dis 1983;60:115-120.

14. Huppke B, Ellenberger D, Rosewich H, Friede T, Gärtner J, Huppke P. Clinical presentation of pediatric multiple sclerosis before puberty. Eur J Neurol 2014;21: 441-446.

15. Waubant E. Effect of puberty on multiple sclerosis risk and course. Mult Scler 2018; 24:32-35.

16. Chitnis T, Graves J, Weinstock-Guttman B, et al. Distinct effects of obesity and puberty on risk and age at onset of pediatric MS. Ann Clin Transl Neurol 2016;3: 897-907.

17. Castilho SD, Nucci LB, Assuino SR, Hansen LO. The importance of memory bias in obtaining age of menarche by recall method in Brazilian adolescents [in Portuguese]. Arq Bras Endocrinol Metabol 2014;58:394-397.

18. Ponsonby AL, Lucas RM, van der Mei IA, et al. Offspring number, pregnancy, and risk of a first clinical demyelinating event: the AusImmune Study. Neurology 2012;78: 867-874.

19. Nielsen NM, Jørgensen KT, Stenager E, et al. Reproductive history and risk of multiple sclerosis. Epidemiology 2011;22:546-552.

20. Runmarker B, Andersen O. Pregnancy is associated with a lower risk of onset and a better prognosis in multiple sclerosis. Brain 1995;118:253-261.

21. Verdru P, Theys P, D'Hooghe MB, Carton H. Pregnancy and multiple sclerosis: the influence on long term disability. Clin Neurol Neurosurg 1994;96:38-41.
22. D'hooghe MB, Nagels G, Uitdehaag BMJ. Long-term effects of childbirth in MS J Neurol Neurosurg Psychiatry 2010;81:38-41.

23. Ramagopalan S, Yee I, Byrnes J, Guimond C, Ebers G, Sadovnick D. Term pregnancies and the clinical characteristics of multiple sclerosis: a population based study. J Neurol Neurosurg Psychiatry 2012;83:793-795.

24. Masera S, Cavalla P, Prosperini L, et al. Parity is associated with a longer time to reach irreversible disability milestones in women with multiple sclerosis. Mult Scler 2015, 21:1291-1297.

25. Jokubaitis VG, Spelman T, Kalincik T, et al. Predictors of long-term disability accrual in relapse-onset multiple sclerosis. Ann Neurol 2016;80:89-100.

26. Koch M, Uyttenboogaart M, Heersema D, Steen C, De Keyser J. Parity and secondary progression in multiple sclerosis. J Neurol Neurosurg Psychiatry 2009;80:676-678.

27. D'Amico E, Leone C, Patti F. Offspring number does not influence reaching the disability's milestones in multiple sclerosis: a seven-year follow-up study. Int J Mol Sci 2016;17:234.

28. Airas L, Jalkanen A, Alanen A, Pirttilä T, Marttila RJ. Breast-feeding, postpartum and prepregnancy disease activity in multiple sclerosis. Neurology 2010;75:474-476.

29. Hellwig K, Rockhoff M, Herbstritt S, et al. Exclusive breastfeeding and the effect on postpartum multiple sclerosis relapses. JAMA Neurol 2015;72:1132-1138.

30. Pakpoor J, Disanto G, Lacey MV, Hellwig K, Giovannoni G, Ramagopalan SV. Breastfeeding and multiple sclerosis relapses: a meta-analysis. J Neurol 2012;259: 2246-2248.

31. Hellwig K, Haghikia A, Rockhoff M, Gold R. Multiple sclerosis and pregnancy: experience from a nationwide database in Germany. Ther Adv Neurol Disord 2012;5: 247-253.

32. Langer-Gould A, Huang SM, Gupta R, et al. Exclusive breastfeeding and the risk of postpartum relapses in women with multiple sclerosis. Arch Neurol 2009;66: 958-963.

33. Portaccio E, Ghezzi A, Hakiki B, et al. Breastfeeding is not related to postpartum relapses in multiple sclerosis. Neurology 2011;77:145-150.

34. Munoz-Price LS, Frencken JF, Tarima S, Bonten M. Handling time-dependent variables: antibiotics and antibiotic resistance. Clin Infect Dis 2016;62:1558-1563.

35. Karp I, Manganas A, Sylvestre M-P, Ho A, Roger E, Duquette P. Does pregnancy alter the long-term course of multiple sclerosis? Ann Epidemiol 2014;24:504-508. 


\section{Neurology}

\section{Menarche, pregnancies, and breastfeeding do not modify long-term prognosis in multiple sclerosis}

María I. Zuluaga, Susana Otero-Romero, Alex Rovira, et al.

Neurology 2019;92;e1507-e1516 Published Online before print March 1, 2019

DOI 10.1212/WNL.0000000000007178

\section{This information is current as of March 1, 2019}

\section{Updated Information \&} Services

References

Citations

Subspecialty Collections

Permissions \& Licensing

Reprints including high resolution figures, can be found at: http://n.neurology.org/content/92/13/e1507.full

This article cites 35 articles, 8 of which you can access for free at: http://n.neurology.org/content/92/13/e1507.full\#ref-list-1

This article has been cited by 3 HighWire-hosted articles: http://n.neurology.org/content/92/13/e1507.full\#\#otherarticles

This article, along with others on similar topics, appears in the following collection(s):

Multiple sclerosis

http://n.neurology.org/cgi/collection/multiple_sclerosis

Prognosis

http://n.neurology.org/cgi/collection/prognosis

Information about reproducing this article in parts (figures,tables) or in its entirety can be found online at:

http://www.neurology.org/about/about_the_journal\#permissions

Information about ordering reprints can be found online:

http://n.neurology.org/subscribers/advertise

Neurology ${ }^{\circledR}$ is the official journal of the American Academy of Neurology. Published continuously since 1951, it is now a weekly with 48 issues per year. Copyright Copyright ( 2019 The Author(s). Published by Wolters Kluwer Health, Inc. on behalf of the American Academy of Neurology.. All rights reserved. Print ISSN: 0028-3878. Online ISSN: 1526-632X.

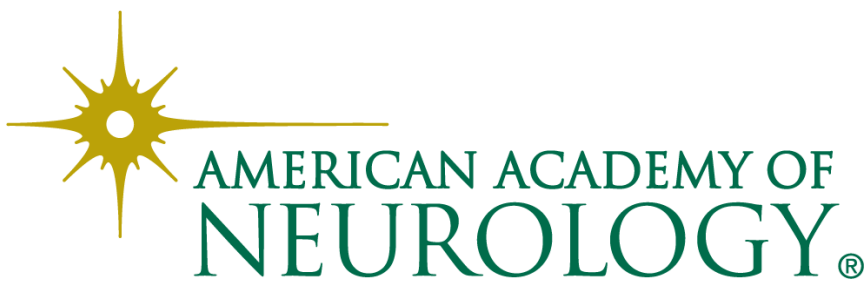

